\section{Maciej Dębski}

Społeczna Akademia Nauk

mdebski@spoleczna.pl

\section{Adriana Krawczyk}

Amsterdam School of International

Business - AMSIB

Amsterdam University of Applied

Sciences

a.c.krawczyk@hva.nl

\title{
Competitiveness of Family Tourist Micro-Enterprises as an Element of Tourist Destination Product
}

\section{ABSTRACT}

Objective: Tourist regions are characterized by a very high complexity and micro-enterprises are the largest group of entities which determine the competitiveness of the destination. However, management of such businesses has a strong specificity. The goal of this paper is to identify the capabilities of managing competitiveness and marketing of this group of entities. Methodology: Literature review, examining and discussing the current knowledge regarding the competitiveness of family tourist micro-enterprises.

Findings: On the one hand, small companies have significant limitations compared to larger companies. However, the family nature of the company allows for high flexibility of management. 
Decisions can usually be made faster and easier, which means that they are able to adapt their offer to the expectations of customers faster and better than large entities. Also, an atmosphere of hospitality and friendship can be easily created. What is more, cooperation with other local entities should result in the ability to offer higher value to consumers.

Value Added: Authors, on the bases of literature review have proposed a model that shows relations as an element of building competitiveness of a family tourist micro-enterprises. It appears that these firms have unique opportunities to develop relationships with their customers. Cooperation, quality and communication have been described as key variables responsible for this process, that should result in generating the benefits of re-selecting the services of the company as well as giving them positive recommendations.

Recommendations: In the area of family businesses in tourism, there is still lack of empirical studies. That is why, the issues presented in this work should be subjected to empirical verification. Future research should concentrate on the specificity of managing a tourist family micro-enterprise and on possible sources of competitive advantage of a tourist family micro-enterprise in the eyes of customers. Especially, described model should be empirically verified. Key words: competitiveness, tourism, destination product, family micro-enterprises JEL codes: M31, M37

\section{Introduction}

Tourism plays a very important role in modern economy; micro-enterprises serve a very significant function for the development of tourist destinations. It should be remembered that tourist regions are characterized by a very high complexity and micro-enterprises are the largest group of entities which determine the competitiveness of the destination. However, management of such businesses has a strong specificity, presenting this specificity is the primary objective of this text.

It seems that the primary source of competitiveness of these enterprises, just like in case of other bigger organizations, can be attractive product, satisfying the needs of the consumer and properly designed system of marketing communication. In contrast, however, even to medium-sized organizations, the businesses in question have significantly lower potential and possibility of developing activities. It should also be noted that there can be in sometimes hundreds of micro-enterprises providing e.g. accommodation 
services in specific destinations. It is hard to stand out in such a group, and then come out with a promotional message. It should also be remembered that tourists choose destination first and it is its attractiveness that is the foundation for their decision. The choice of specific place of accommodation is of secondary nature.

One must not forget that tourism has a spatial, often international, dimension. The product of the company is sold to the customer, usually being situated in a different place, who has no possibility of its direct verification. As a result, the opinion of the company, its recommendations become especially important, the promotion has its own specifics as well. Characteristic features of management of a tourist micro-enterprise, and especially of a family tourist micro-enterprise are numerous. The aim of this study is to identify the specificity and capabilities of managing competitiveness of this group of entities. As emphasized by D. Getz, J. Carlsen, A. Morrison (2004, p. 2), there is a deficit of knowledge and studies in this area and it is certainly worthwhile to replenish these deficiencies.

\section{Essence of tourist destination product}

J. Kulawik-Dutkowska states in one of her studies that 'micro, small and medium-sized enterprises are the backbone of Polish and EU economy' (2014, p. 73). It is hard to argue with this statement. The discussed group of companies determines a number of processes in the economy, which is confirmed by the figures. For example, as shown in the report of the Polish Agency for Enterprise Development SME sector is responsible for the creation of close to 50\% of Gross Domestic Product, and the micro-enterprises alone generate approximately 30\% of GDP (Raport o stanie małych i średnich... 2015, p. 15). A characteristic feature of this type of businesses is the fact that a significant part of them have family character. Given the importance of this group of companies as a creator of economic growth, or a player on the labour market, it is appropriate to seek all possible management tools 
that could strengthen small and medium-sized family businesses, build their potential or generate any competitive advantage.

Small and medium-sized family businesses are also an important element of the tourism market (Zapalska \& Brozik, 2007, p. 142). They are these actors that create a tourist destination product in a very powerful way, being responsible especially for the development of accommodation, gastronomy and transport infrastructure.

To determine the role of family small, medium-sized and especially micro-enterprises in the tourism market, it is necessary to define the nature and specifics of the product destination. It can be divided in two key spheres (see Fig. 1). The first of them includes natural values, anthropogenic (manmade) values and all kinds of events of cultural and other character. This part of the tourism product largely determines whether tourists come to the destination. Besides, the area product further comprises the infrastructure of a region or place, which includes: a base of accommodation and catering, communications network and travel agencies that make up the basic infrastructure - targeted mainly at tourists. Another important element of the infrastructure is its complementary part, which was created primarily for the residents, but it is used by tourists as well. 
Figure 1. Tourist destination product

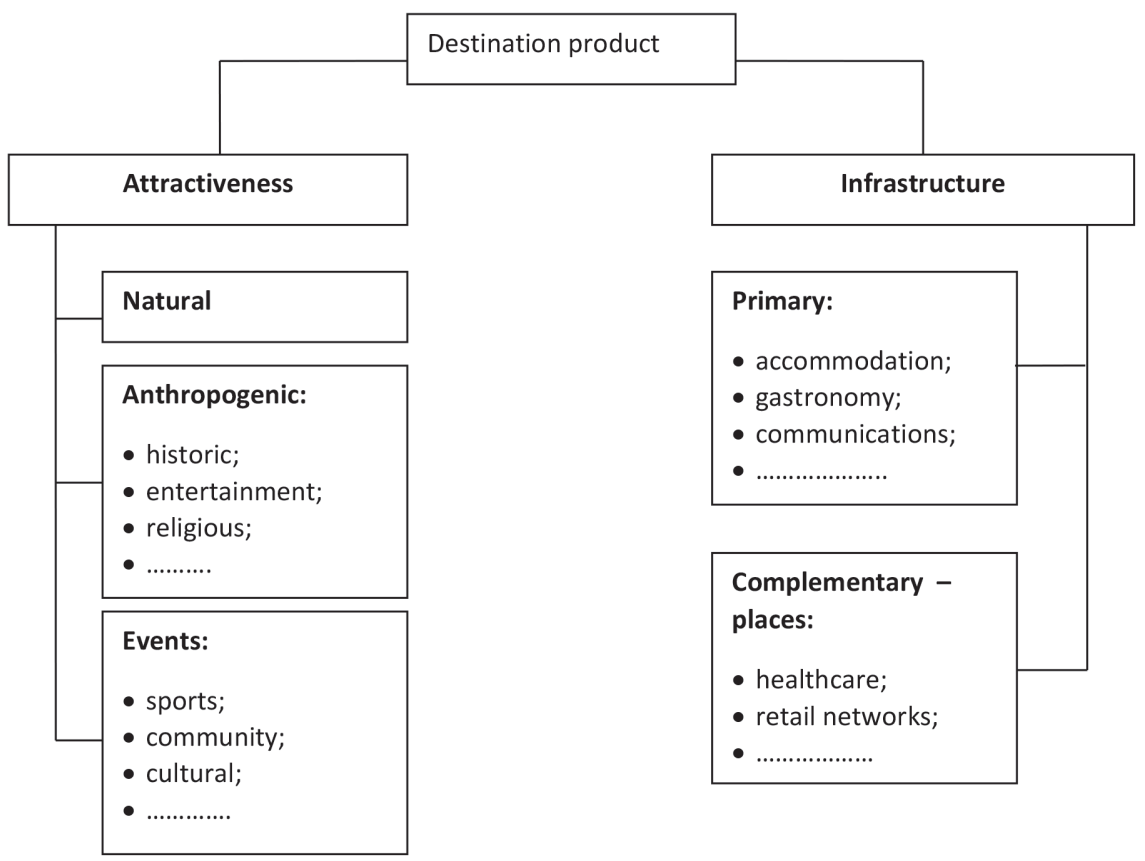

Source: author's study.

Regardless of the definition being adopted, there is a consensus regarding one issue. Destination product is characterized by high complexity and is made up not only by tourist attractions, but it is also created by companies operating in the region that largely determine its competitiveness. Adopting the classification of the tourist product presented in Fig. 1, it should be noted that family tourist micro-enterprises play a significant role, being primarily responsible for the creation of infrastructure. It is the local businesses, usually of family nature of the ownership that form a significant part of both primary and supplementary spheres. 


\section{Family businesses as an element of tourist destination product}

As indicated earlier, important destination stakeholders, having a significant impact on the development of its product and competitiveness are family entrepreneurs. For example, as noted by M. Bednarczyk perpetuated dominance of micro, small and medium enterprises and family roots of entrepreneurship in tourism belong to the essential characteristic features of entrepreneurship on the Polish tourism market (Bednarczyk, 2006, p. 39). D. Getz, J. Carlsen and A. Morrison (2004, p. 3) in turn write that family businesses are in many areas the foundation of competitiveness of destinations. These statements indicate the importance of the mentioned group of enterprises on the tourism market, which is due to several reasons.

Firstly, it should be noted that in the literature there is no dominant definition of a family business, this is a category that has not been precisely defined. This group accommodates both large entities as well as small, locally operating, companies. Comprehensive verification of the definition of family businesses has been performed by H. Harms (2014) who analyzed 267 articles from scientific journals. On the other hand, as Ł. Sułkowski (2011, p. 10) points out, there may be different criteria for the differentiation of family businesses, e.g. family ownership structure, exercising strategic control by the family, participation of family members in the management or the involvement of more than one generation in the company's operations. At the same time, however, this author states that family businesses constitute a very important group among small and medium-sized enterprises (SMEs). And it is SMEs that are the dominating group of entities co-creating the destination product, being especially responsible for the infrastructure in the given area. Adopting this approach allows to put forward a hypothesis about the importance of family businesses for building the competitiveness of a destination.

Another condition indicating the significance of family micro-enterprises in the tourist destination is generated by a look at the stakeholders of destina- 
tions. As indicated by Ph. Kotler, M. Halin, I. Rein, D. Heider (2002) the residents and entrepreneurs belong to the key groups. It seems that family businesses are an important platform to connect these groups, since the inhabitants of destinations are usually the owners of local businesses. Such situation is beneficial from the point of view of building competitiveness because it leads to a stronger identification of entrepreneurs with the destination and increases the willingness to get involved in its development.

As is often emphasized in the literature, management or operation of family businesses is strongly conditioned by the culture of a country or region. For example, Hitchcock and Wesner (2009, pp. 265-282) describe precisely the impact of the Confucian philosophy on the functioning of the Vietnamese family businesses. They emphasize, among others, that the teachings of Confucius show a strong respect for the family, which has a positive effect on ensuring the continuity of management by the same family. In countries where there is still a strong attachment to family values, this could have a positive impact on the involvement of members of the family in the functioning of enterprises belonging to them. P. Bartkowiak and P. Niewiadomski (2012, p. 12) point out that the essential characteristic of the family business is a man, or men who founded it, their energy and commitment often decide about the success of their initiative.

Another important element for the development of competitiveness of destinations is cooperation. Especially in the case of local destinations, an important factor stimulating cooperation is the existence of informal relations, interpersonal links, which is confirmed by empirical research (Hankinson 2009, p. 105; Warnaby, Bennison \& Barry 2005, pp. 191-192). The existence of this type of relationship has a positive impact on cooperation and certainly makes it easier to carry out a number of joint ventures. It seems that these relationships are stronger in the case of entities that are owned and managed by people permanently associated with the given destination.

Certainly, one cannot ignore the fact that family capital is less mobile. Family businesses, due to the attachment of the owners, are more likely to 
generate an investment in the destination, reducing the tendency to seek new locations. It can therefore be assumed that the family capital, in the case of families living in a given location for several generations, will be associated with it stronger.

\section{Specific character of family businesses - management and marketing}

\subsection{Management}

Family ownership of businesses creating destination product, responsible for its competitiveness, possesses of a number of positive aspects but there are also significant weaknesses and limitations resulting from their specificity. They are indicated in aggregate way in Table 1.

Table 1. Weaknesses and limitations related with family ownership of tourist enterprises

\begin{tabular}{|l|l|l|l|}
\hline Ownership & $\begin{array}{l}\text { Business environ- } \\
\text { ment }\end{array}$ & Marketing & $\begin{array}{l}\text { Business opera- } \\
\text { tions }\end{array}$ \\
\hline $\begin{array}{l}\text { Easiness to start } \\
\text { the activity en- } \\
\begin{array}{l}\text { courages people } \\
\text { without formal } \\
\text { qualifications }\end{array}\end{array}$ & $\begin{array}{l}\text { A large share of } \\
\text { illegal activities } \\
\text { among the owners } \\
\text { of family business- } \\
\text { es in tourism }\end{array}$ & $\begin{array}{l}\text { Orientation on one } \\
\text { segment of the } \\
\text { market }\end{array}$ & $\begin{array}{l}\text { No planning / strat- } \\
\text { egy }\end{array}$ \\
\hline $\begin{array}{l}\text { Lack of professional } \\
\text { managers }\end{array}$ & $\begin{array}{l}\text { Strong competition } \\
\text { Lack of research }\end{array}$ & $\begin{array}{l}\text { Expenditures not } \\
\text { always aimed at } \\
\text { development }\end{array}$ \\
\hline
\end{tabular}




\begin{tabular}{|l|l|l|l|}
\hline $\begin{array}{l}\text { No development } \\
\text { strategy for next } \\
\text { generations }\end{array}$ & $\begin{array}{l}\text { Location of the } \\
\text { projects is often } \\
\text { unattractive }\end{array}$ & $\begin{array}{l}\text { Lack of knowledge } \\
\text { on marketing ac- } \\
\text { tivities }\end{array}$ & $\begin{array}{l}\text { Relatively low } \\
\text { quality of services, } \\
\text { often there is no } \\
\text { customer-orien- } \\
\text { tation }\end{array}$ \\
\cline { 2 - 4 } & $\begin{array}{l}\text { Large number of } \\
\text { bureaucratic ob- } \\
\text { stacles }\end{array}$ & $\begin{array}{l}\text { Large dependence } \\
\text { on the season }\end{array}$ & $\begin{array}{l}\text { No use of new } \\
\text { information tech- } \\
\text { nologies }\end{array}$ \\
\cline { 3 - 4 } & $\begin{array}{l}\text { Possibility of mis- } \\
\text { understandings } \\
\text { between family } \\
\text { members }\end{array}$ \\
\hline & & $\begin{array}{l}\text { Low economy of } \\
\text { scale }\end{array}$ \\
\hline
\end{tabular}

\section{Source: Petric 2003, p. 1760.}

It can be assumed that majority of the indicated weaknesses of tourist family businesses are due to their limited size, which will probably only deepen in the case of micro-enterprises. Their size and related financial restrictions result in the lack of a number of professional managerial activities. Certainly at the moment of starting the company, its functioning and development carry a significant risk. In such a situation entrepreneurs have a certain, although understandable, reluctance to invest in professional management. It seems, however, that as the business grows, when it has started to function in a stable manner, the acquisition of knowledge and managerial skills by either the founders or their descendants should be a condition stimulating its further development.

For all family businesses, including the ones operating on the tourist market, a significant barrier to development is to ensure the continuity of ownership and management of the company by a given family (Tassiopoulos, 2008, p. 281). Two groups of factors limiting the issue of succession in one family can be pointed out. The first is rather universal, factors such as the lack of descendants, significant 'age gap' between parents and children or reluctance of the descendants to continue the family tradition are all problems regardless of the industry in which the family company operates. The second 
group of factors discussed by D. Tassiopoulos concerns the specifics of the tourism industry, which is the reason of the following:

- location of the company may be unattractive for young people, for locations in rural areas or in small towns there is a strong tendency to leave for educational purposes to the larger cities, which may lead to staying in there and unwillingness to take over the family business. - working conditions (long hours, limited privacy, strong contacts with customers) are seen as unattractive for a lot of people, which may also discourage from running this type of business.

One of the issues related to the management of family tourist micro-enterprises are limitations in this area. Additionally, one can indicate a strong specificity of management of the discussed activities, which also has a positive side. It should be noted that the characteristic feature of micro-enterprises (and these are predominant in the formation of destination product), including the family ones, is high flexibility of management. In such companies decisions can usually be made faster and easier, which means that they are able to adapt their offer to the expectations of customers faster and better than large entities.

Moreover, family businesses (especially in the area of accommodation services) like no other can create an atmosphere of hospitality and friendship. In tourism, this feature results in building strong relationships not only with the environment of the given destination, but also in relation to customers, which increases their loyalty. As Presas, Munoz and Guia point out in their study (2011, p. 270), family companies have a number of special intangible assets, which guarantee their uniqueness and can translate into building their brands. These values are listed by the authors and called familiness, which clearly refers to the importance of the family for the management of the company. At the same time, however, it should be remembered that Tassiopoulos (2008, p. 276) strongly emphasizes that family businesses in tourism usually require a strong involvement and frequent contacts with customers (the dominance of services in tourism) resulting in strong interference in family life and can affect it in the negative way. 
Another feature is the fact that family businesses in the destination, as already mentioned, are usually formed by the residents. These people are emotionally connected with it, but at the same time have often lived there for generations. Consequently, they have a stronger capital of relations to create cooperative relations with other companies than entrepreneurs who came into the area, and as indicated it is the cooperation that can be a significant source of competitive advantage of a tourism business.

Figure 2. Relations as an element of building competitiveness of a family tourist micro-enterprise

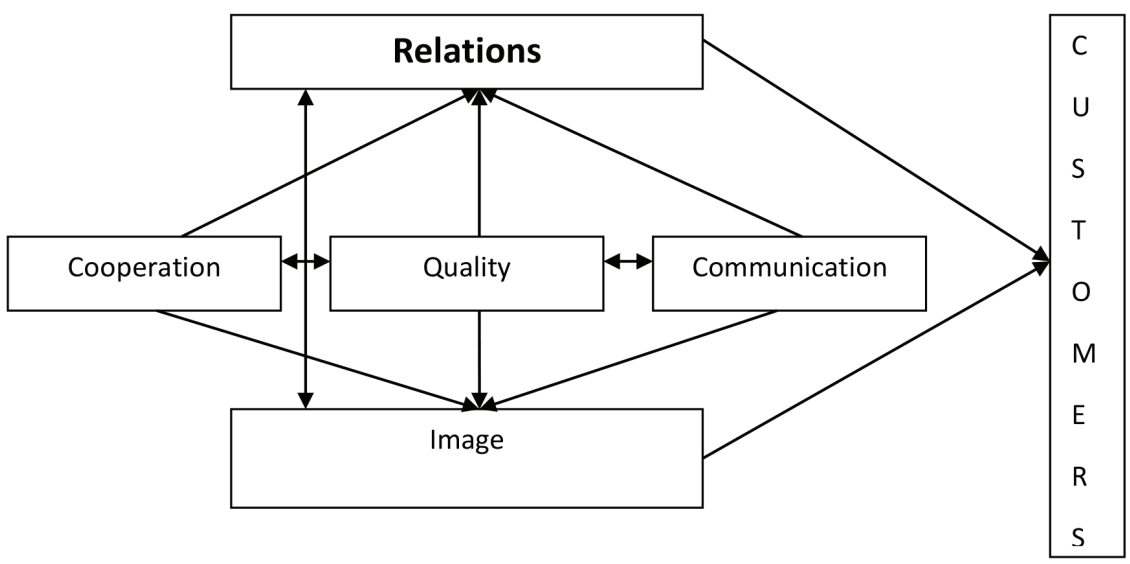

Source: author's study.

Analyzing the specifics of management in micro-enterprises a model of building competitive advantage can be proposed in tourism, which is shown in Figure 2. It appears that the described entities have unique opportunities to build relationships with customers-tourists. For further considerations it has been assumed that building positive relationships with tourists generates the benefits of re-selecting the services of the company as well as giving them positive recommendations. Cooperation, quality and communication have been decided as key variables responsible for developing relationships with clients. The first of these variables relates to cooperation with other 
entities and should result in the ability to offer higher value to consumers. As mentioned, owners of family businesses in tourism are usually people strongly associated with destination, the area where they operate, which should be reflected in potential for development of all forms of cooperation, generating mutual benefits.

Another area, or the foundation for building any relationship, is the quality of the product, in principle, its assessment and satisfaction associated with this assessment. In the area of accommodation infrastructure, in the vast majority of cases family micro-enterprises certainly have limited opportunities to compete with hotels or apartment complexes, which are an increasingly common form of the providing such services. Described businesses are usually smaller and poorer furnished. At the same time, however, they may try to stand out thanks to the commitment of the owners, their hospitality and creating a friendly atmosphere, while taking care to ensure the physical elements of the object at the highest level.

The third, but no less important element of developing the relationship with the customer is marketing communication. It is a tool most responsible for making the tourists use the services of the company. However, bringing its role only to attract customers is a simplification and a mistake. Properly conducted communication should be responsible for maintaining relations with the tourist after he leaves the destination, it should be focused on building loyalty and making the tourist use the products of the company once again and give the company a positive recommendation. Unfortunately, also in this respect family micro-enterprises have fewer financial resources than their larger competitors. Besides, one should not forget about the competence gap in terms of knowledge of marketing tools mentioned before, which can only partly be compensated by the enthusiasm and commitment of the owners.

All three of these tools serving to build relationships also affect the image of the company. Furthermore, it is of course in a strong interaction with developed relations, together influencing the behaviour of tourists. While 
managing the competitiveness of a tourist micro-enterprise, the manager is less able to shape these two variables than a larger competitor.

\subsection{Marketing}

There is a significant advantage of a tourism micro-business regarding the choice of marketing strategies. Namely, such company has an opportunity to build relationships and image based on the family nature of the company. At the same time, there are certain issues that restrict marketing tactics. Petric (2003) names some of the limitations, such as orientation on one market segment, lack of marketing knowledge, absence of research (see Table 1). Family micro-enterprises certainly have limited opportunities to compete with hotels or apartment complexes. Even when facing the mentioned limitations, such aspects as owners' commitment, hospitality, local experience, small scale should be highlighted in marketing communications.

Remarkably efficient and cost effective to connect with customers is the use of social media technologies, which have generated fundamentally new ways of interacting. The digital marketing landscape has changed along with the customer behavior. People are more motivated to engage and interact through social media for social connection, entertainment, information access. Consequently, this has increased customers' consumption, participation, but also production of information of the companies' social media platforms (Heinonen, 2011). With the growing use of social media, a company has a presence in a wider variety of places than ever before (Bradley, 2010). Unlike traditional media that are often cost prohibitive to micro-enterprises, a social media strategy does not require astronomical budgeting (Hanna et al., 2011).

Social media is one of the fastest growing media in history (Richardson, Choong, \& Parker, 2016). Online social networks are web communities (Armstrong \& Kotler, 2011) for consumers to engage, socialize, exchange opinions and information. Different types of platforms are available such as; Twitter, Facebook, Instagram, blogs, Linkedln, YouTube and Snapchat. There are 2.307 
billion active social media users with an annual growth of 10\% since 2015 (Chaffey, 2016). Facebook offers various types of targeting opportunities for marketers to create a personalized ad-type, fan pages, subject groups. Twitter is mostly known for the updates on news and events with 328 million active monthly users worldwide with the vision to give their users the power to create and share ideas and information instantly, without barriers (Practice, 2017b). Instagram is a social media platform owned by Facebook that enables sharing videos and photos and has over 700 million users (Practice, 2017a) while being one of the fastest growing social media channels nowadays. The platform offers great opportunity for businesses to promote their brand.

The advantages of social media marketing for tourism micro-enterprises is that companies can develop communication strategies that both reach and engage people in numerous ways, on platforms that do not require expensive media spends and creative development (Hanna et al., 2011). Social media is an effective tool to reach a wider audience and create a great amount of brand awareness in a short period of time. All social media platforms may be linked, which increases an interaction across them. The sooner a company becomes involved in social media, the sooner it takes an advantage of it (Bradley, 2010).

Concluding, considering the specificities of tourism family micro-enterprises, best marketing strategies would be those that require neither much financial resources nor the technical skills, highlighting the features that small-scale accommodations offer at the same time. Developing social media marketing strategy is ideal for those businesses.

\section{Summary}

As considerations indicate, tourist destination product is a product with a strong specificity. It is mainly a result of its complexity, it is not only the composition of a large quantity of individual products but also of all the advantages available in the given area. Due to the characteristics of the 
destination product, it is the entrepreneurs (including family businesses) who are the stakeholder group, which has a significant impact on the competitiveness of the place, while being at the same time a group which derives many benefits from the development of tourism. To maximize the effectiveness of entrepreneurs' participation in building the competitiveness of the destination, a strong horizontal collaboration between them is necessary as is the cooperation with the local administration.

It seems that family businesses are a group of entrepreneurs which has a strong effect on the development of the destination (their owners are closely linked to it), including the intensification of links between its stakeholders. Management as well as marketing operations of these entities, however, involve a very strong specificity. On the one hand, they have significant limitations compared to larger companies. At the same time, however, especially in the case of accommodation services, they have specific advantages resulting from the family nature of the company.

It should be noted, however, that in the area of functioning of family businesses in tourism, there is a strong paucity of empirical studies, relatively little research is carried out. Consequently, it seems that the issues presented in this work should be subjected to empirical verification, in search of, among others, answers to the following questions: What is the share of family businesses among companies developing destination products, do family businesses have a stronger desire to participate in joint ventures for the development of the competitiveness of the destination, what is the specificity of managing a tourist family micro-enterprise, what can be a source of competitive advantage of a tourist family micro-enterprise in the eyes of customers? 


\section{References}

Armstrong, G., \& Kotler, P. (2011). Marketing an introduction. Essex: Pearson Education.

Bartkowiak P., \& Niewiadomski P. (2012). Efektywne zarządzanie firmą rodzinną kompetencyjne wyzwania sukcesji. Research Papers of the Wrocław University of Economics, Issue 262, pp. 11-24.

Bradley, P. (2010). Be where the conversations are: The critical importance of social media. Business Information Review, 27(4), pp. 248-252.

Chaffey, D. (2016). Global social media research summary 2016. Smart Insights.

Getz, D., Carlsen, J., \& Morrison, A. (2004). Family business in tourism and hospitality. CABI Publishing, Oxfordshire.

Hanna, R., Rohm, A., \& Crittenden, V.L. (2011). We're all connected: The power of the social media ecosystem. Business Horizons, Vol. 54, Issue 3, pp. 265-273.

Hankinson, G. (2009). Managing destinations brands: establishing a theoretical foundation. Journal of Marketing Management, vol. 25, issue 1-2, pp. 97-115.

Harms, H. (2014). Review of Family Business Definitions: Cluster Approach and Implications of Heterogeneous Application for Family Business Research. International Journal of Financial Studies, 2, pp. 280-340.

Heinonen, K. (2011). Consumer activity in social media: Managerial approaches to consumers'social media behavior. November [online] , http://onlinelibrary.wiley.com/ doi/10.1002/cb.376/full, access: $2^{\text {nd }}$ November, 2016. 
Hitchcoch, M., \& Wesner, S. (2009). Vietnamese values, networks and family businesses in London. Asia Pacific Business Review, Vol. 15, Issue 2, pp. 265-282.

Konkurencyjność małych i średnich przedsiębiorstw na polskim rynku turystycznym (2006). M. Bednarczyk (red). Kraków: Wydawnictwo Uniwersytetu Jagiellońskiego.

Kotler, Ph., Halin, M., Rein, I., \& Haider, D. (2002). Marketing Asian Places. Singapore: John Wiley\&Sons.

Kulawik-Dutkowska, J. (2014). Prawidłowe określenie statusu MŚP w kontekście korzystania z pomocy publicznej przez przedsiębiorstwa. Internetowy Kwartalnik Antymonopolowy i Regulacyjny, No 9 (3), p. 73.

Petric, L. (2003). Small and family business in the tourism and hospitality industry - challenges and obstacles. In: Proceedings of the 5th International Conference on Enterprise in Transition Split: Faculty of Economcs, pp. 1747-1770.

Practice, W.B. (2017a). What we know about marketing on Instagram. WARC.

Practice, W.B. (2017b). What we know about marketing on Twitter. WARC.

Presas, P, Munos, D, Guia, J. (2011). Branding familiness in tourism family firms. Journal of Brand Management, Vol. 18, Iss. 4/5, pp. 274-284.

Raport o stanie małych i średnich przedsiębiorstw w Polsce w latach 2013-2014 (2015). Warszawa: PARP, p. 15.

Richardson, P.S., Choong, P., \& Parker, M. (2016). Social Media Marketing Strategy: Theory and Research Propositions. Journal of Marketing Development and Competitiveness; West Palm Beach, 11. 
Sułkowski, Ł. (2011). Definicje i typologie małych firm rodzinnych - wnioski z badań. Przedsiębiorczość i Zarządzanie, tom XII, zeszyt 6, Firmy rodzinne - determinanty funkcjonowania i rozwoju. Współczesne aspekty zarządzania. Łódź: SWSPiZ.

Tassiopoulos, D. (2008). New Tourism Ventures. An Entrepreneurial and Managerial Approach. Juta, Cape Town.

Warnaby, G., Bennisson, D., \& Davies, B. (2005). Marketing town centres: Retailing and town centre management. Local Economy, Vol. 20, No 2, pp. 183-204.

Zapalska, A., \& Brozik D. (2007). Managing family businesses in the tourism and hospitality industry: the transitional economy of Poland. Journal of Economics and Business, Vol. 25, Issue 1, pp. 141-165. 